\title{
Creating Waste Coconut Coir as A Creative Art
}

\author{
M. Zaim ${ }^{1, *}$ Refnaldi $^{1}$ Yofita Sandra $^{1}$ Rifqi Aulia Zaim ${ }^{1}$ \\ ${ }^{1}$ Universitas Negeri Padang \\ ${ }^{*}$ Corresponding author. Email: mzaim@fbs.unp.ac.id
}

\begin{abstract}
Issues related to maintaining the balance of nature and preserving regional culture have long been the focus of implementing community service as one of the lecturers' activities when carrying out higher education duties. The campus's role is expected to drive economic growth in rural communities as part of the implementation of the application of science and technology that comes from the academic community. However, until now, there is still a limited number of lecturers who encourage local people to maximize their area's potential, especially those related to agriculture. Pakandangan area, Padang Pariaman Regency, West Sumatra, is rich in coconut. All parts of the coconut tree, such as the trunk, leaves, fruit, and coconut roots, can meet daily needs and are known as zero-waste plants. There are no people who have the knowledge and skills to process coir into souvenirs whose selling price is even higher than the coconuts themselves. Through design methods, training, and workshop activities, strategies are arranged so that the community can get double benefits from their crops. The community is motivated to be observant about the situation and trends that are developing and appropriate the work. With a simple design, coir waste can be created into beautiful souvenirs.
\end{abstract}

Keywords: coir waste, skills, souvenirs, income

\section{INTRODUCTION}

Producing new products from available natural resources is the main alternative to increase people's income. Nagari Pakandangan has great opportunities related to these alternatives. So far, the use of coconut is more emphasized on the fruit's function, which is used as the main ingredient in making traditional West Sumatra regional dishes, namely rendang. Meanwhile, the processing of waste, starting from coir and coconut shell, tends to be neglected [1]. Several studies have found that coconut waste can be used as various useful objects, such as coir used as mats, car seats, landfills for marsh roads, spring bed lining, cocopeat, and rope [2]. The findings in the field show that there are no people of the Pakandangan community who are experts in processing coconut waste, let alone making it a souvenir. However, the price of souvenirs made of coconut shells or coconut husks that have been processed in such a way has a selling value that is even higher than the price of the coconut itself.

The official website of the Padang Pariaman Regency Government published data in 2013; coconut has become the dominant crop cultivated by farmers so that it has become a commodity that dominates markets both within and outside the region. The community can sell 10,000.00 pieces per day from a production area of $34,722.00$ hectares with a total production of 512.7 tons per year, and this number has increased by $10 \%$ every year until 2017 to 825.8 tons per year. So far, farmers have only dared to set a price of Rp. 2,000, - / grain or starting from Rp. 3000, '/ grain to Rp. 7,000, - / item on the market.

This price is still relatively low, considering the small wages earned by farmers compared to market traders who distribute the products to the broader community. Coconut has high economic advantages that have succeeded in penetrating domestic and even foreign markets. This is because it is known that the fruit is not only used as an essential ingredient in traditional West Sumatra dishes, it will also be used as raw material for various other functional objects that are used as equipment for daily community activities.

One of the causes of the community's minimum income is due to a lack of knowledge to process the resources around them [3], including coconut plants that grow in many communities. Therefore, on this occasion, we will describe in more detail the ways and processes of coconut waste processing so that it can become a new source of income for the community, especially after the first year of developing souvenirs from coconut coir powder or cocopeat to become a key chain toy decoration. Zulherman (2018) [7] and Maulidyah \& Sakundria (2008) [8] state that from coconut trees, various materials have the potential to be used as new products, starting from coir, shells, and sticks made of coconut leaves. Meanwhile, there is no community group in Nagari Pakandangan, a sub-district of Enam Lingkung, which has a workshop for processing coconut waste into souvenirs. Apart from the limited number of experts, it is also due to a lack of information regarding tools and materials that can be used to process coconut husks and shells into suitable souvenirs to become export commodities.

So far, coir and coconut shell waste has only been used as a substitute for firewood for cooking traditional Minangkabau dishes, not only as fuel for making bika, but also for cooking rendang and other dry or wet pastries. Even though with a few more touches of coir and coconut shells, they can have a higher selling value if they are processed into a typical souvenir of the Pakandangan 
village, sub-district of Enam Lingkung, Padang Pariaman District as having been carried out by Hadi, Widyaningrum, \& Bahri (2018) [1] and Fitriyah \& Ciptadi (2018) in processing regional-based community economies, because many people do not know the process of making these souvenirs. Fitriyah \& Ciptadi (2018) used coir waste as a natural dye in fashion products. Thus, it is considered essential to hold training and workshop regarding how to process coconut into souvenirs in a practical, effective, and efficient manner. The campus will significantly contribute to improving the community's abilities and skills, which will lead to efforts to improve community welfare.

\section{DISCUSSION}

The processing of coir into souvenirs can be grouped into two-dimensional products and three-dimensional products. Two-dimensional products can be paintings and wall decorations. A three-dimensional product can be a hollow object or filled with air and can be filled with something. Some steps that can be taken to create new creations are taken by observing similar products from other regions, creating opportunities for finding new variants and inserting existing cultural values in society. The following will be explained the steps for making souvenirs from coir.

The first step is to develop ideas for processing coir by adopting findings created by people in other areas. Specifically, several examples of wind chimes produced by craftsmen from other regions were found for wind chimes.

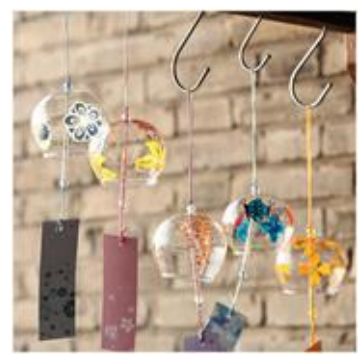

(a)

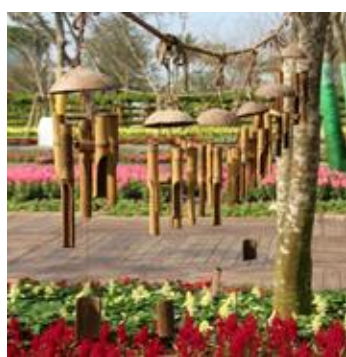

(c)

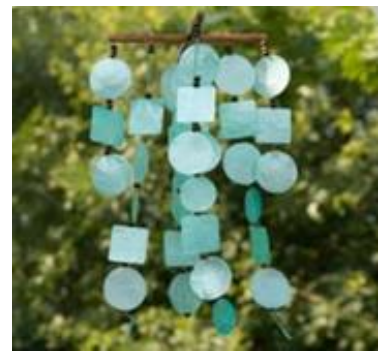

(b)

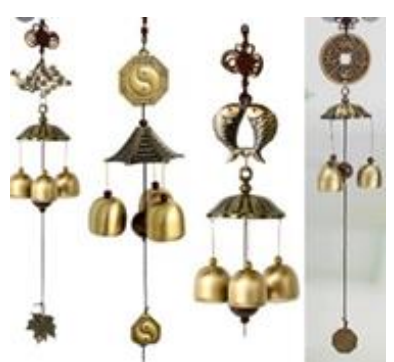

(d)
Picture 1. Wind chimes that have been produced outside the region/country
Note:

(a) glass wind chimes

(b) wind chimes of paraffin

(c)bamboo wind chimes

(d) wind chimes of cast engineering brass [9]

Wind chimes like these can be a decoration for indoors and even outdoors. The collision between hanging elements will produce sound when blown by the wind. This becomes something interesting to create in other forms, on this occasion with coir material.

The second step is to make coir a new variant in the new wind chime production process. When coir does not produce sound, metal is added to produce the sound so that it does not take away from the essence of the wind chime character itself.

The third step is to include elements of local culture in the product. Nagari or city icons, either in architecture or tourist attractions, can be the central theme. At this stage, the image of a particular object on a piece of paper is affixed with coir. The coir sticking process can be done using a glue gun. Individual parts that are considered to have a convex impression can be made thicker, and by adding the outline contours of the wool yarn material, new creations can be produced.

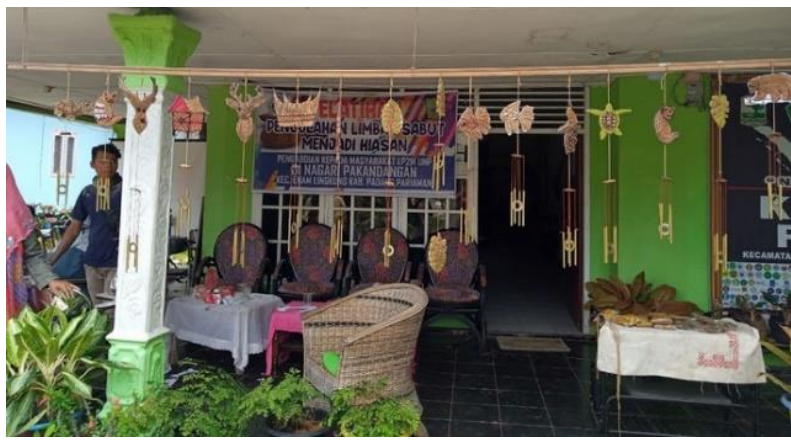

Picture 2. Wind chimes made of coir material produced by the Pakandangan community after training and workshop

It can be seen in picture 2, the product that features Rumah Gadang and Rangkiang made of coir as an idea for creating wind chimes. Besides that, there are also sea turtles because, in Pariaman, there is a turtle breeding center. Thus, the regional icon can be conveyed in this new product.

A similar work-making process can be applied to creating different coir creations. Judging from various sources, it is known that natural materials or certain types of preparations can be made into the decoration, for example, in the textile sector. The ability to sew patchwork or make makarame is directed at meeting the tourism and industry sectors' needs. 

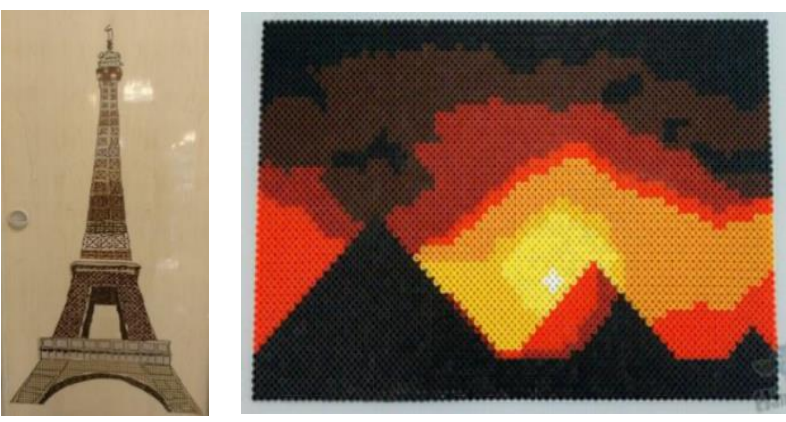

Picture 3. Textile creations to produce tourist icons in France (the Eifel Tower) and Egypt (the Pyramids of Giza)

Based on the idea above, coir originating from Pakandangan Pariaman or other areas can be used as a souvenir in a new form. The product is photographed, and text is added through the Corel Draw or Photoshop program. One activity to process coir in the form of an object can be made into two products. This was possible when the wind chime product was the first product, which was then eternalized through photographic techniques and mass-produced. In the form of stickers, the resulting objects can amount to tens or even hundreds.

Meanwhile, in the form of wind chimes, there is only one processed product. The advantages and disadvantages of each product can be anticipated by frequently processing coir into decoration. Widiawati, Rais, Haryudant, \& Amanah (2007) [10] state that the coir creation was worthy of being a souvenir or souvenir for tourists visiting from other areas; of course, the local cultural icon had to be highlighted.

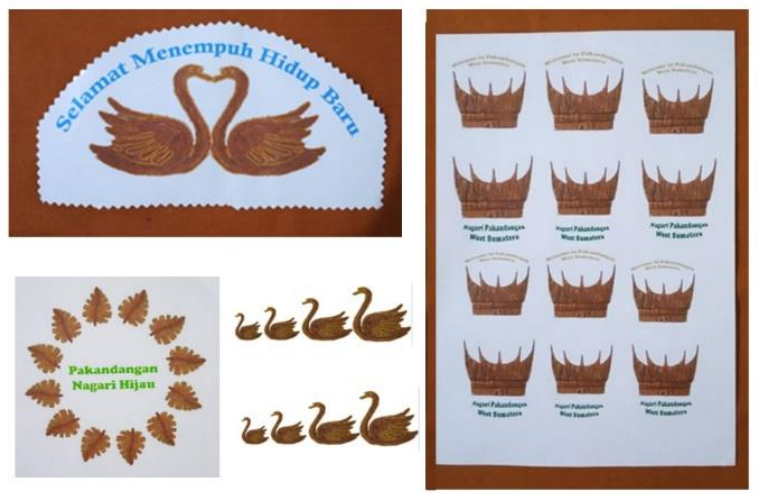

Picture 4. Coir sticker products from photos with text added using the Corel Draw or Photoshop programs

The opportunities to duplicate coir creations in various formations, sizes, and shapes can be created using a computer program. This is in line with developments in technology and information. Through a cell-phone camera, the product can be eternalized and written as additional information. The products can be printed in large numbers and distributed to various tourist attractions.

\section{CONCLUSION}

Through the application of design methods, training, and workshop, the community can benefit significantly in order to be able to maximize the potential of their area. Although they do not have special skills such as drawing or painting, people can produce superior and competitive products as befits a craftsman. In other words, processing coir into souvenirs is not difficult to follow up. The team's training, workshop, and mentoring made it easier for the community to gain new access to alternative sources of income [11]. Coconut coir never goes wrong, and if it has not been sold short, it can still be used as a home decoration waiting for buyers' orders. The decorative motifs that are offered can also be used to preserve local cultural values, which of course become an attraction for tourists from outside the region or abroad.

\section{REFERENCES}

[1] MasFikr, Kerajinan Tangan dari Batok Kelapa dengan Bentuk yang Unik dan Menarik. https://masfikr.com/kerajinan-tangan-dari-batokkelapa/ 2019 (downloaded, 12 Februari 2019)

[2] Sanjaya, G. Perancangan Kursi Santai Berbahan Tempurung Kelapa Untuk Kolam Renang Tropis Lembab. Jurnal Intra, 6(2), 2018, pp. 531-535

[3] Zaim, M., Refnaldi, Sandra,Y., \& Zaim, R.A. Varian baru pada Produk Olahan Limbah Sabut Kelapa untuk Dijadikan Souvenir Berdaya Jual Tinggi. Abdi Humaniora: Jurnal Pengabdian Masyarakat, 1(1), 2019, pp. 41-47

[4] Zulhelman, Pembuatan Kaligrafi Islam dari Bahan Limbah di MAN 3 Padang Panjang. Jurnal Abdimas Mandiri, 2(2). 2018

[5] Maulidyah, A.P. dan Sakundria, S.M.W. Desain Lampu Tempurung Kelapa Sebagai Pengolahan Limbah Berbasis Teknologi dan Kriya. SENASeminar Nasional Desain dan Arsitektur, 1., 2018

[6] Jawa Pos. Dari Limbah Batok Kelapa Menjadi Kerajinan Bernilai Tinggi. https://radarsemarang.com /2017/06/06/dari-limbah-batok-kelapamenjadikerajinan-bernilai-tinggi/, 2017 (didownload, 12 Februari 2019)

[7] Hadi, D. S., Widyaningrum, M., dan Bahri, S. Usaha Produksi Kerajinan Sapu Berbahan Serabut Kelapa Berbasih Wilayah. International Journal of Community Service Learning. 2(2), 2018

[8] Fitriyah, H., \& Ciptadi, F. Pengolahan Limbah Sabut Kelapa Tua Sebagai Pewarna Alam Pada Produk Fesyen. E-Proceedings of Art and Design, 5(3), 2018

[9] Id.aliexpress.com. Lonceng Angin dari Kaca. https://www.google.co.id/imgres?imgurl=https\%3A $\% 2 \mathrm{~F} \% 2 \mathrm{Fae} 01 . \mathrm{alicdn} . \mathrm{com}, 2020$ 
[10] Widiawati, D., Rais, Z., Haryudant, A, dan Amanah, E.S. Pemanfaatan Limbah Sabut Kelapa Sebagai Bahan Baku Alternatif Tekstil. Jurnal Ilmu Desain, FSRD-ITB, 2(1), 2007

[11] Ratmanida, Hafizh, Noor. Pemberdayaan Ekonomi Kelompok Masyarakat Sadar Wisata Kawasan Mandeh Bahari Melalui Progam Pelatihan ESP Bahasa Inggris Pariwisata di Kabupaten Pesisir Selatan. Abdi Humaniora, 1(2), 2020 